\title{
IN SERVICE OF THE SPIRIT OF SEXUALITY: SETTING BOUNDARIES AS AN ACT OF TRANSGRESSION ${ }^{1}$
}

\author{
Annelise Erasmus \\ University of Pretoria
}

\begin{abstract}
In this contribution, the condition of the Spirit of sexuality, which can also be read as a proxy for Spirit found in all spheres of life, is discussed. This Spirit has a specific definition arrived at by merging the most pertinent aspects of spirituality, Rausch, the erotic and Will to Power. It is argued that Spirit is in trouble and that the human rights movement may have inadvertently been one of the reasons for its demise. Optimal conditions for calling forth the Spirit of sexuality as well as the conditions for its weakening are suggested and the actions and philosophies which lead to this weakening analysed. Boundaries as transgression in a society, which insist on openness, are ultimately proposed as a way to rehabilitate Spirit.
\end{abstract}

Keywords: Sexuality; Spirit; Erotic; Hegel; Transgression

\section{A tale of consequences}

I wish to stand up for Spirit (see description below). In this essay, it will be argued that Spirit is dying or may have perished already. Like all things metaphysical, Spirit is not something which can be held in one's hand. It is the result of specific values and circumstances, and just like the proverbial flame, it can easily be extinguished. Spirit may not have been targeted directly or on purpose, but the argument that will be made here is that the human rights culture may inadvertently have been detrimental to Spirit, and specifically to the spirit of sexuality.

In building this argument, I will first define Spirit as it is used here. By appropriating Hegel's master-slave dialectic, the optimum conditions in which Spirit is summoned will be discussed. Spirit can easily be destroyed, and by considering the influence of the human rights culture, it will be argued that it already has. Various tactics that were and are used by the movement, as well as their influence on Spirit, will be explored before a proposal for the possible rehabilitation of Spirit will be suggested.

\section{Spirit}

The victim in this story is Spirit, but it can also be argued that humanity will become the victim if Spirit dies. We may already have lost an important part of ourselves. For the purpose of this argument, Spirit has a specific meaning. The working definition of Spirit 
proposed here encompasses the concepts of spirituality, the erotic, Rausch and Will to Power.

The definition of Spirituality accepted for the purpose of this article is the one coined by Lombaard (2009:107):

Spirituality may be described broadly as the orientation people have to the "big questions" of life. Their orientation to issues such as the meaning or purpose of life, whether or not there is life after death, the existence or not of gods, or a god, or God, and whether all these may be experienced, or may be expressed in this life. These are all existential/experiential matters that cannot be studied in any academic way.

Sexuality is one of the "big questions" of life which combines internal values with the way it is expressed in an intensely personal way.

Nietzsche (1973:92) argued that a person's sexuality influences the very core of his/her spirit. In the argument made here, such a "spirit of sexuality" will be applied as proxy for Spirit found in all spheres of life.

Another concept that is incorporated in this working definition of Spirit is eroticism. The latter, as formulated by Morris (2013:8), will suffice. She defines eroticism as:

some form of transcendent experience fuelled by sexual desire, complicated by transgression, and exhibiting resistance to language. And if we accept that eroticism is a place where language breaks down, then we must be prepared to find bliss, as Barthes says, between the cracks and in the silences.

This eroticism meets spirituality in the concept of Eros described by Carr (2003:9):

This is a vision of Eros as flavouring all of life. Many people experience such passion most in sexual longing and fulfilment. But others know similarly intense passion when playing music, windsurfing on a sunlit bay, or discussing a new and exciting idea with a friend. So often, the word erotic is taken as equivalent to 'sexual.' Yet the word Eros originates in Greek culture, where it included all sorts of core desires: certainly the sexual, but also intellectual, artistic, and spiritual yearning.

Rausch, another aspect of Spirit as defined here, was seen by the early Romantics as a transgression of the boundaries between humans and nature, focusing on the individual's experience. Rausch, translatable roughly as something like a euphoric and intoxicating ecstasy, is a sweeping away of someone by the forces of existence, taking him/her back to the primordial and animalistic, to before the birth of civilisation (Lebovic 2004:3).

Came (2014:185) wrote that:

(i)f there is to be any aesthetic doing and seeing, one physiological condition is indispensable: Rausch. Rausch must first have enhanced the excitability of the whole machine; else there is no art. All kinds of Rausch, however diversely conditioned, have the strength to accomplish this, above all, the Rausch of sexual 
excitement ... Also the Rausch that follows all great cravings, all strong affects; the Rausch in destruction; the Rausch under certain meteorological influences, as for example the Rausch of spring; or under the influence of narcotics; and finally the Rausch of an overcharged and swollen will.

This leads to Will to Power - the last aspect of the working definition of Spirit - which is essentially an active, self-disruptive and eternal self-overcoming. Nietzsche's Will to Power is "a paradoxical formulation, a force that, unlike resolve or striving wills itself outside itself. Through the Will to Power we know ourselves as out beyond ourselves ... a thrill of pleasure announces to us the power attained, a power that enhances itself' (Gordon 2001:13).

Thus, four dimensions to Spirit as understood here have been identified, namely of spirituality, the erotic, Rausch and Will to Power.

Spirit, it is argued here, does not merely exist. Specific conditions must exist for Spirit to be present. Some classic writers such as Hegel and Nietzsche will be referred to in a philosophical attempt to reflect on a contemporary issue. Hegel's master-slave dialectic can explain these conditions. His narrative about the Battle for Recognition (Fukuyama 1992:193) is an example of a situation where Spirit is born. Spirit lives and sometimes dies in a "moment." The Battle for Recognition includes all that is needed for such a moment.

\section{Summoning up Spirit}

Hegel, in the context of this essay, can be seen as the father of Spirit. At the very least, he has described through his master-slave dialectic the circumstances in which Spirit is born.

A condensed rendition of his master-slave dialectic would be something like this (Erasmus 2017):

Once, before time, there was a man alone in his natural state. He desired to be desired by others - to be recognised by them. He could not see himself and needed someone to make him real. His sense of identity and worth was connected to how others saw him. One day this man encountered another man. At first, he was elated because he could recognise himself in the other person, and he revelled in their sameness. Man, however, wanted to be recognised as man, and this meant being recognised as someone who was able to risk his life. This led to a violent struggle between the two men - a struggle to be recognised by the other. At the end of this battle a winner and loser emerged. The one decided to submit to a life of slavery rather than die. The victor became his master.

This is the moment that leads to action. This is the moment of pure Spirit - the moment of energy and possibility. What the action will be, makes all the difference for the argument being made in this essay.

"The need is felt to overcome this particularity, to reinstitute one's own universality as ground of value, and there is thus an attempt to solicit the recognition from the other of one's own absolute freedom and independence. The two interlocutors 
hence both try to bring their subjective self-certainty of their value to objective expression. Each desiring subject asserts its master-slave dialectic independence and self-identity by negating the other desiring subject" (Reynolds 2009:12-13).

From this, this author contends that it seems that desire to resolve the conflict is a driving force. It summons up Spirit, as defined previously. In line with the focus on sexuality, it is also interesting to note how Hegel saw love:

Hegel conceived of love as an interpersonal relationship of mutual recognition in which the 'natural' individuality or uncultivated self is confirmed (rather than one's social role or contribution to the community). Even sexual relationships involve the reciprocity of knowing oneself in the other in sexual relations; both subjects can recognise themselves in their partner, since each one desires to be desired by the other. In Hegel's view, sexuality thus represents the first form of the unification of opposing subjects (Sinnerbrink 2007:115).

Fukuyama (1992:176) points out that sexual conquest is more than just a physical gratification for which a partner is not always needed. The subjects also desire to be desired by the other. It wants to be desirable. The self that is being recognised is not necessarily the same as the self of Hegel's aristocratic master, but when it comes to deep, erotic love, even the slave longs to be recognised as something more than the sum of his/her physical characteristics. The longing is for recognition of one's worth. It is this longing that fuels Spirit.

\section{Killing Spirit softly}

Spirit can sadly also be killed. In an ironic twist, Hegel creates the optimum conditions for Spirit and then proceeds to work towards dismantling this Spirit through negation. The reason Hegel's master-slave narrative is referred to in this article is not because of the end of history he envisages when all tension is negated, but because of the moment of recognition - the moment from where all movement springs. The focus here is the spiritual-sexual possibilities of that moment.

In this article, negation is seen as a negative force. Negation, as defined here, is derived from Hegel's dialectic method where negation is the dynamic aspect that flows from contradictions of categories or identities. Through negation, the static categories are dissolved and adapted to push history forward towards a "whole."

By negation or contradiction, Hegel means a wide variety of relations difference, opposition, reflection or relation. It can indicate the mere insufficiency of a category or its incoherence. Most dramatically, categories are sometimes shown to be selfcontradictory (Spencer and Krauze 1996:14).

Hegel overcomes the particular to move towards a whole, but the whole does not disregard the specific identity or category. Nothing is destroyed; it is raised and preserved like in a spiral (Spencer and Krauze 1996:14).

Is it not possible to extrapolate that Hegel sublimates the "moment" shortly after creating the conditions for it (or, at the very least, he immediately starts working towards its 
negation) and so turns it into something that is non-sexual, or sex without Spirit? He is guilty of destroying the moment he created - the moment of tension - by dissolving the tension.

It can be argued that Spirit in sexuality is negated in the same way. Žižek (2012: 7) explains Hegel's philosophy of marriage as follows:

The true Pascalean formula of marriage is therefore not: 'You don't love your partner? Then marry him or her, go through the ritual of shared life, and love will emerge by itself!' On the contrary, it is: Are you too much in love with somebody? Then get married, ritualise your love relationship in order to cure yourself of the excessive passionate attachment, to replace it with boring daily custom - and if you cannot resist the passion's temptation, there are extramarital affairs ...

Society's approach towards sex has always been to extinguish or control its Spirit. In this regard, Žižek (2012:7) says that sexuality is the area where humans detach from nature. Sexuality is not a natural foundation of human lives. In the animal world, sexual perversion or deadly passions do not occur. When Catholics preach that sex should only be for procreation and that sex born of lust is animalistic, they make a mistake. Sex for procreation is the way of the animal sphere.

Spirit is thus institutionalised and negated. Tension created by the feelings of passion experienced in the "battle" (desire) for recognition is released as soon as possible and by any means.

\section{For the common good}

It is the contention of this author that Spirit has been negated as an unintended consequence of the liberal ideal. Kojève may be a good example of this philosophy.

Sinnerbrink (2007:136) wrote that “( $(t)$ he novelty of Kojève's approach was to generalise Hegel's account of the Struggle for Recognition across human history, combining it with the Marxist thesis of the centrality of class struggle in historical development." Amending Hegel, Kojève believed that we have reached the end of history by overcoming the opposition and tension between master and slave. He contended that history has begun to institutionalise forms of mutual recognition and that this institutionalisation would make historical action (war, conflict and social struggle) all but redundant.

We have arrived at the 'end of history' a condition of post-historical freedom where the institutional conditions for mutual recognition, and hence freedom, have in principle been achieved. For Kojève the Struggle for Recognition drove history from the first bloody battle; history has ended because the universal and homogeneous state embodying reciprocal recognition fully satisfied this longing (Fukuyama 1992:288).

Kojève understood the costs of modern democracy. In a sense, he understood that Spirit would be lost. "For if man is defined by his desire to Struggle for Recognition, and his work in dominating nature, and if at the end of history he achieves both recognition of 
his humanity and material abundance, the 'Man properly so-called' will cease to exist because he will have ceased to work and struggle" (Fukuyama 1992: 310).

Despite this realisation, Kojève continued working towards this end. The end of history means the disappearance of historical man. When that happens,

Kojève believes that art, love and play will become merely personal pursuits again. Postmodern subjects will have material abundance and complete security in a new consumer society, but they will not be happy. "On the contrary, they will be content as a result of their artistic, erotic, and playful behaviour, inasmuch as, by definition, they will be contented with it. Cultural aestheticism, mass consumerism and personal hedonism will be our banal forms of post-historical satisfaction" (Sinnerbrink 2007:143). Spirit, it can be argued, will not live there anymore.

Circling back to the theme of this essay, it is put forward that inhumane times in history gave birth to moments when Spirit, which was needed to lead us to a better world, came into existence. The atrocities of Nazi-Germany propelled us into action; we started to create a world where people would never again be portrayed as some"thing" which has no rights. Fukuyama (1992:311) also commented on this dichotomy when he wrote that "(h)uman life, then, involves a curious paradox: it seems to require injustice, for the struggle against injustice is what calls forth what is highest in man." This is exactly the Catch-22 situation we find ourselves in: injustice calls forth Spirit, which arouses our Superman which is sacrificed (negated) to become Human, all too human ${ }^{2}$. Hegel also focused on our humanity, but unlike Nietzsche who wanted to overcome our humanity, Hegel saw liberal society as preserving a positive aspect of the human personality, namely his non-selfish part. Hegel sought to put that non-selfish part at the centre of modern political society (Fukuyama 1992:145).

It is this writer's contention that the "natural" Spirit of sexuality also needs special circumstances to flourish and that these circumstances are threatened by the same enemy - negation of tension for the common good. In the case of sexuality, the tension that is negated is not only found in a Struggle for Recognition between the lovers, but also between the "areas" where sexuality flourishes (private) and the public. This tension is being negated in the quest for equality, and this is where the Spirit of sexuality is threatened. In the private realm, where societal judgement and morality has no place, the Spirit of sexuality can be called forth. By violating this private realm and turning it into something else (the social and political), the mandate of the liberal ideal was overstepped, and Spirit was wounded.

\section{Breaking down boundaries in an effort to break down tension}

Since the Second World War, society has focussed on removing boundaries. Humankind saw the horrifying results to which boundaries and difference could lead and decided to break them all down in the name of freedom and equality. Some of the boundaries that fell in the ensuing Battle for Recognition of everyone and everything were the boundaries between private and public, men and women, normal and "kink", and even morality and immorality.

To save everyone, the private could not be allowed to stay private. 
Definitions of private and public have, as would be expected, changed quite dramatically through the ages. Today, personal computers and the World Wide Web have forced us to re-define the spheres yet again. It may be helpful to look at how privacy was defined and experienced through the ages.

Ariès $(1989$, p. 1) writes that humans first started with no privacy. In feudal times there was not room for personal autonomy and solitude. The acts of daily life would be performed in public. At most, places were recognised where a precarious intimacy could take place like a quiet spot in the forest or a corner of a hallway or a hut.

Arendt (1958:28) elaborates on aspects of the "private" and "public" based on ancient Greek thought. She says that the difference between the private and public spheres of life matched the household and political realms in the ancient city-state. They were seen as distinct, separate entities. The home and family were at the centre of a natural sphere. This space was in direct opposition to the political sphere. In the city-state, a man had two "lives" - a private life and political life - and there was a definite distinction between what was his and what was communal (Arendt:24). The most important attribute of the private/household was that it was driven by the inhabitants' needs and desires. Life itself was the driving force. For the survival of the species, man and woman was needed, each with his/her own responsibilities. Man laboured to provide food and woman laboured giving birth - all in service of life. "Natural community in the household therefore was born of necessity, and necessity ruled over all activities performed in it" (Arendt:30).

Habermas (1974:49) says that by "the public sphere" we mean first a realm of social life in which something approaching public opinion can be formed. Access is guaranteed to all citizens. A portion of the public sphere comes into being in every conversation in which private individuals assemble to form a public body.

A third realm, the social realm, is a new occurrence that came into existence in the modern age and found a political form in the nation-state. What is important for the argument this dissertation wants to make here is Arendt's concern with our difficulty of understanding the divide between public and private and between the polls and the household because of the development of the social. This divide is also between activities that relate to a shared world and activities related to the tasks of maintaining life - a dissection that was the basis of all ancient political thought and was unquestionable. Today, that division is blurred because we see groups of people and political communities as families who need to be looked after by someone or, rather, by an administration. This super-family is now called a society and its political organisation is called a nation (Arendt:28).

Mabille (2016:1) says " $(\mathrm{t})$ he birth of the intimate sphere is closely associated with the explosion of individualism in the eighteenth century, its emblematic figure being Jean-Jacques Rousseau with his search for authenticity." Rousseau did not rebel against the oppressive state but against society's "perversion of the human heart" by intruding into the most intimate part of humankind. Before then, this innermost part did not need any protection. "The intimacy of the heart, unlike the private household, has no objective tangible place in the world, nor can the society against which it protests and asserts itself be localised with the same certainty as the public space" (Arendt 1958:38).

The private has been immensely enriched through modern individualism. It is, however, important that it must be opposed to the social as well as to the political. The 
most relevant function of modern privacy, according to Arendt (1958:38), is to shelter the intimate. This, it is argued here, did not happen.

Tuttle (1986:296) has observed that sex and sexuality has been taken from the private and been made public by feminist discourse. In a way foreshadowed by Foucault's observation that the discourse on sexuality has much to do with power and foregrounding, "( $\mathrm{t}$ )he concept of sexual politics is at the very heart of modern feminist theory. Like the slogan 'the personal is political' it represents a different way of thinking about male-defined reality, and connects two areas ( private $=$ sexual + public $=$ political) which had previously been presumed to be dichotomous" (Tuttle 1986:296).

Echoing some aspect of Hegel's Struggle for Recognition, Arendt says that our experience of reality depends on appearance and appearance depends on the existence of a public sphere where something can "appear" out of the private and intimate. There are, however, a lot of things that cannot survive being exposed to others in the public scene. As an example, she chooses love, as opposed to friendship, as something that can only survive in the private realm. She says it is

extinguished, the moment it is displayed in public. Because of its inherent worldlessness, love can only become false and perverted when it is used for political purposes such as the change or salvation of the world ... Indeed, the most intense feeling we know of, intense to the point of blotting out all other experiences, namely, the experience of great bodily pain, is at the same time the most private and least communicable of all (Arendt 1958:52).

This sounds exactly like Spirit as the opening section to this contribution described it.

Erotic tension - Spirit - is destroyed when private is not private. Sometimes, for this tension to exist there must be a taboo attached to the situation. In this regard, religion, by declaring sex taboo, may have inadvertently been good for Spirit. Some sub-cultures are all about the taboo attached to it and about being "underground." A lot of these were opened and "explained" in an attempt to rescue the participants from perceived discrimination or inequality. An example of this was the $\mathrm{BDSM}^{3}$ subculture, which was "ousted" by the Fifty Shades of Grey (James: 2011) books.

\section{Breaking down difference in an effort to break down tension}

Another variation of the struggle for recognition can be found between the genders. This may be the area where the most damage to the Spirit of sexuality occurred and where the war of negation was fought most passionately. In feminist theory, "sameness" sometimes refers to same sex or queer theory. This is not what is meant here. The focus of this essay is heterosexual relationships, and other sexual identities are only important in so far as they overstep their own concerns and negatively influence heterosexual relations. This, sadly, happens regularly when a minority of the (sexual) population tries to obliterate gender. "It is one thing to attack other interpretations so as to keep dominating and winning over competing world views; it is another to attack the very source of new

BDSM - "The initials refer to many concepts, including Bondage, Discipline, Domination, Submission, Sadism, Masochism, Sadomasochism and related subcultures of Domination/submission, Bondage and Discipline, and Sadomasochism" (Edmunds 201:13) 
challenges, the physiological and intellectual qualities which certain human beings possess" (Tomasi 2007:168).

What a strange position we find ourselves in. We are Hegel's masters and slaves, still caught in the struggle. The slaves are emancipating themselves while also lying in the arms of their masters. Some slaves find themselves in a daily struggle for equal rights and equal opportunities while their bodies burn with desire dreaming about submitting to that same master. The same can be said of men, the current "masters of the universe." While most support women in their quest, it is not always clear how the sexual sphere should change because, for most, this sphere functions different from the rest.

Irigary (1993:12-13) approaches this question from a more metaphysical angle. In An ethics of sexual difference, she writes that

... to arrive at the constitution of an ethics of sexual difference, we must at least return to what is for Descartes the first passion: wonder. This passion has no opposite or contradiction and exists always as though for the first time. Thus, man and woman, woman and man are always meeting as though for the first time because they cannot substitute one for the other. I will never be in a man's place; never will a man be in mine. Whatever identifications are possible, one will never exactly occupy the place of the other - they are irreducible one to the other... Who or what the other is, I never know. But the other who is forever unknowable is the one who differs from me sexually. This feeling of surprise, astonishment, and wonder in the face of the unknowable ought to be returned to its locus: that of sexual difference.

Describing something akin to the definition of Spirit used in this dissertation, she says that the passions have been distinguished or repressed and reduced. Wonder is not found anywhere except maybe in art. It is never found between man and woman. She says that in the place of wonder came "attraction, greed, possession, consummation, disgust..." But the wonder that would see something as if for the first time and never see the other as an object to own does not exist. This wonder would not try to possess but would leave it free. "This has never existed between the sexes since wonder maintains their autonomy within their statutory difference, keeping a space of freedom and attraction between them, a possibility of separation and alliance" (Irigary 1993:13).

It may appear as if Nietzsche criticised the liberal state. It will be argued that this is not the case. He does, however, criticise the push toward equality that leads to sameness. For him, the will to power and struggle is more important than a will to survive or to merely persevere. He believed that diversity and struggle would lead to a stronger culture. Kelner (1991:14) states the following:

Nietzsche believed that mingling of different races and the development of a multicultural society in which different groups competed would create a stronger European polity that would overcome the banal nationalisms and national chauvinisms of his day. Moreover, Nietzsche constantly theorized gender, class, national, and ethnic differences and thus emerges as a theorist of difference against the homogenising trends of modernity and the tendencies of theorists to wipe out these differences in a more generalised concept of human beings. 


\section{Spirit lives where boundaries meet}

For Nietzsche, ancient Greek civilisation was preferred to modern culture's homogeneity and jejuneness ${ }^{4}$. They had a vital culture because they accommodated conflicting ideas, values, and lifestyles. In most of his work, Nietzsche contrasts a Dionysian culture against an Apollonian lifestyle. "Dionysian culture was eminently life affirming, expressive of bodily energies and passions, and bound together individuals in shared cultural experiences of ecstasy, intoxication, and festivals, which Nietzsche believed created strong and healthy individuals and a vigorous culture." This Greek culture of "suffering and redemption" created a "tragic pessimism' that in turn created the conditions in which philosophy and great art led and redeemed humanity and produced healthy and strong societies (Kellner 2000:7).

It can be argued that this is the equivalent of the discord and tension caused by Hegel's Struggle for Recognition. The struggle for balance between the Dionysian and Apollonian is the moment when Spirit comes into being. This Spirit leads to greatness.

The society Kojève wished to see can be equated to Socratic culture. Kojève negated the Spirit he found in Hegel's master/slave narrative in the same way Socratic sensibilities negated Greek passion. For Kojève, human history, which is basically Hegel's Struggle for Recognition, ends when the opposition is suspended. "At this point, true equality through mutual recognition is achieved in what Kojève calls the "universal and homogeneous' political state ('universal' in the sense of upholding the principle of equality for all, and 'homogeneous' in the sense of eliminating cultural, religious, ethnic and other particularities in favour of equal citizenship)" (Sinnerbrink 2007:140).

A healthy conversation or struggle between these conflicting moralities could have (in keeping with the argument put forth in this essay) been the catalyst for action, for Spirit. But this is not how slave morality functions. Slave morality promised a heaven in the future where salvation awaits in return for obedience and submission to institutions and social forces. In this way, powerlessness and ressentiment was turned into social control and discipline - "herds" who obey the dominant morality. For Nietzsche, the result of this subjugation through the repression of the body was the frustration of instincts (Kellner, 2000, p. 6).

A mini narrative may look like this: After fighting for basic human rights, liberal activists eventually campaigned for the freedom to be anyone you want to be. This led to the refutation of biological and sexual differences, amongst other such denials. This emphasis on personal identity led to no-identity and a sameness because everyone became non-descript rather than unique. Does the denial of natural/traditional/biological identities lead to the experience of "all interpretations are false" rather than the intended "experiences of all interpretations are special and valid?" Nietzsche also described this apparent dichotomy. "He saw Christianity, morality, and social conformity levelling individuals into a homogeneous herd, and fragmenting into incommensurate social groups. Both tendencies have indeed accelerated since Nietzsche's day ..." (Kellner 1991:25).

We live in the era of slave morality. It can be said that the Struggle for Recognition became a struggle to be recognised as a victim. Choose your identity, choose the specificity of your victimhood, become interdependent, and disappear as an individual. 
This happens when morality oppresses the individual by controlling his/her behaviour through universal and restrictive structures. Morality is inherently something that oppresses individual drives and passions because it is universal. It leads to "excessive subjectivism and inwardness, creating unhealthy concerns with guilt, shame, and conscience" (Kellner 2000:10).

To be able to enforce a specific morality, there needs to be an enforcer. It is also important that society is receptive to this. “... Hegel's Aufhebung (sublimation) of the will is therefore not merely individual self-control, but the explicit socialisation of man's interest. It is the explicit recognition by the will that the satisfaction of individual needs lies in social interdependence and interaction" (Houlgate 1986:15).

This levelling negated struggle, and without struggle it can be said that a crisis of authenticity arose. Without struggle the "pre-Socratic discord" Nietzsche looks for in a society and Irigary's "wonder," all disappear. This, for Nietzsche, was nihilism. And what is nihilism if not a condition without Spirit?

In Nietzsche on the Cross: The Defence of Personal Freedom in The Birth of Tragedy, Borody (2003:80) writes that "ecstasy as a human experience has always been micromanaged by the powers that be, whether by the Alpha males of primitive hunter-gatherer tribes or the bureaucratic power-functionaries of the Modern State." The managing of morality is one such example. It is the opinion of this author that the moment of Spirit cannot contain morality. Morality has to do with the moment after that, the action following the moment of tension. If that action is the negation of the life-affirming contradictions, Spirit will die.

\section{Setting boundaries means freedom}

As a remedy for the demise of Spirit, I argue that Nietzsche's "method" will lead to the creation of more moments of Spirit. As has been explained throughout, Hegel's Struggle for Recognition determines the moment of tension from which the Spirit of action flows, but (especially as appropriated by Kojève and some modern liberal movements) his method also leads to negation of this tension. It may be said that universalising recognition inevitably trivialises and de-values it (Fukuyama 1992: 301). Deleuze saw Nietzsche and Hegel as direct opposites. An objection to Hegel's dialectics is that it negates difference and plurality and can therefore not perceive individuation and something "new" (Sinnerbrink 2007:174).

Is it possible to continue creating moments of Spirit through the tension of struggle, but without the assumption that the moment needs to be sublimated and ritualised? A natural dissolving of the tension (which is inevitable) may then be followed by the creation of consecutive moments of tension instead of trying to negate the tension permanently. A marriage between Hegel and Nietzsche for the sake of Spirit is what is proposed.

Nietzsche is anti-dialectics. In Hegel's case, the process of self-reflection only happens once. In Nietzsche's view, it is a recurring and continual event (Houlgate 1986:10). Sublimation, for Nietzsche, is self-overcoming. It is the control of the instinctual self by the rational self. But the control Nietzsche advocates, is not a negation of Spirit. It can even be said that it is done because of Spirit.

Nietzsche was the modern-day champion of thymos (roughly spiritedness). He reacted to the rise of a civilisation without Spirit. He saw the coming of a society of men 
who wanted nothing more than their own comfortable self-preservation. "For Nietzsche, the very essence of man was neither his desire nor his reason, but his thymos: man was above all a valuating creature, the "beast with red cheeks" who found life in his ability to pronounce the words "good" and "evil" (Fukuyama 1992:188).

For the argument being made here, it is important that Nietzsche is not read as rejecting modern reason and rational enquiry. The point is exactly that he tried to reestablish balance. He called for a reconstruction of Enlightenment. Even negation was not seen as purely negative. Nietzsche believed that a specific kind of sublimation would lead to strong, healthy bodies and personalities. He criticised the repression of natural drives which lead to cruelty and guilt through the conscience. Against this selfrepression, he proposed a sublimation that will refine the natural instinct creatively (Kellner 2000:9).

Rubavičius (2006:69) writes that postmodern thinking is awash with the idea of overcoming or flouting of countless boundaries. These ideas are informed by the concept of transgression. He argues that reflecting on a boundary assumes a possibility that it may be crossed - the act of grasping a boundary mentally is already a crossing of it and this will in time be converted into creative or real action. Boundaries are also confirmed and strengthened through social and cultural struggle. This creates individual and group identities that connect the body, consciousness, and territory (Rubavičius 2006:68).

Transgression itself is being "transgressed" or negated through this process. This is, however, not necessarily true. Rubavičius writes that

(a)n important feature of recent approaches to transgression is that transgression is increasingly understood as a condition of both established and emerging norms as well as of all kinds of identities and normalities. It is the idea George Bataille has infused into much of postmodern theory: what transgression does is not to negate the taboo, but to transgress and complete it. Transgression is needed in order to institute and establish all kinds of boundaries (Rubavičius 2006:69-70).

\section{Transgression and the Spirit of Sexuality}

According to Paglia (2017:26), the Dionysian side of human nature is best understood through human sexuality. She argues that men created culture and civilisation, which reflects our Apollonian side, to contain women, who symbolise Dionysian forces. She argues that sexual freedom and liberation are modern delusions. "We are hierarchical animals. If we destroy one hierarchy another will come in its place. Both nature and society have hierarchies. In nature it is kept in place by brute force and in society by protection of the weak. Civilisation is our barricade against nature."

Can this be an attempt to return to Spirit? Paglia refers to a "point" where two opposing forces meet. This dissertation calls it the moment of stuggle/tension. She calls it by a different name: She contends that

“... (s)ex is a far darker power than feminism has admitted. Behaviourist sex therapies believe guiltless, no-fault sex is possible. But sex has always been girt round with taboo, irrespective of culture. Sex is the point of contact between humans and nature, where morality and good intentions fall to primitive urges. I called it an intersection. This intersection is the uncanny crossroads of Hecate, 
where all things return in the night. Eroticism is a realm stalked by ghosts. It is the place beyond the pale, both cursed and enchanted" (Paglia 1991:3).

As an example, BDSM can be defined as transgressive sex. In When equal becomes the same. The spirituality of sex: Have we lost it? (Erasmus \& Lombaard 2017), BDSM was proposed as an example of a sexual experience that may summon up the Spirit of sex by playing with boundaries. Although the suggestion still stands, the cure may also contain traces of that which will kill Spirit in the end. BDSM emerged as a pharmakon of Spirit.

Nietzsche's Will to Power and Hegel's Master-slave dialectic can both be found in a BDSM scene. In a BDSM situation, the slave is not really a slave and subordinate to the master outside of the scene. As opposed to the slave in Hegel's dialectic, this master is recognised by another "master" even though they pretend to take on different roles for a while. The tension does not come from the desire to be recognised as such because the recognition has already taken place. The tension and moment of Spirit comes from "reversing" that recognition and pretending that the hierarchal roles they agreed to assume are real - at least for the duration of the play.

BDSM is a problem for today's liberal society. The insistence by some on, for example, a link between the female submissive/masochist and the fact that it mimics battered women denies the essence of the whole lifestyle. The reason for this uncertainty is the very character of a BDSM scene. Cloudiness is intentionally part of the game. To start with, the BDSM mantra, "safe, sane and consensual" is blurred and not easily determined. "(I)t is because SM is characterised by a subtle play of resemblance and dissimilarity, a structure of risk, that, for its practitioners, accounts for much of its seductive appeal - and, indeed, lends it much of its subversive potential" (Burrus \& Moore 2003:48).

Accusing women of internalised patriarchy is a "paternalistic" and even arrogant allegation, because it denies the authenticity of desires that do not fit into the current moral landscape. By that accusation, the accuser lays claim to knowledge of an ultimate truth which the other apparently cannot see or comprehend. This policing of women's sexuality and fantasies is a way of breaking down the private-public boundary. Criticising BDSM also shows the poor understanding of the lifestyle by those watching from the outside. A submissive may be male or female, and (as explained previously) in BDSM the power lies with the submissive (of any gender). It is exactly the requirements of liberal society that leads to the over-ritualisation of BDSM and, as we have seen, this ritualisation leads to the negation of sexual Spirit.

MacKendrick comes to the rescue of Spirit by stressing that "context is everything." Each of the "counterpleasures" (as she calls transgressive sex) make perfect sense in their own social and historical context (MacKendrick 1999:11).

Without boundaries, we do not have context. Boundaries are like weights: they weigh us down, but weightlessness is also unbearable. "In the face of the threats of a total weightlessness, an unbearable lightness of being, a universal promiscuity and a linearity of processes liable to plunge us into the void, the sudden whirlpools that we dub catastrophes are really the thing that saves us from catastrophe" (Baudrillard 1993:69). Transgressive sexual practices can be seen as creating a whirlpool which can revive the spirit of sex in the same way that playing along the boundaries of all aspects in life tend to ignite spirit. MacKendrick (1999:17) writes that what most forms of transgressive sex 
have in common are "love of boundary-play." This is wrongly understood as a dislike of limits or a desire to shock society. She says they "delight in the existence of boundaries, that they may be broken and overleapt; in the establishment of limits, that they may be surpassed."

Nietzsche famously argues that good health and self-satisfaction may be liabilities. Thymos will seek out struggle and sacrifice to prove to the self that it is better and higher than an animal driven by fear, instinct and need (Fukuyama 1992:305). Not all men are inspired by this struggle just like not all people are attracted to transgressive sex, but for those who are, boundaries against which to frame the struggle are important.

Transgression needs the law. For transgression to become jouissance, an opposite principle is needed. Jouissance incorporates both movements - pleasure as well as the constraint of the law (Zukauskaite 2003:6). Sexual transgression acquires a positive meaning through Foucault (1977:30-35) when he says:

"the only division possible in a world now emptied of objects, beings, and spaces to desecrate ... Profanation in a world, which no longer recognises any positive meaning in the sacred - is this not more or less what we may call transgression? It ... must be liberated from the scandalous or subversive, that is, from anything aroused by negative associations. Transgression does not seek to oppose one thing to another, nor does it achieve its purpose through mockery or by upsetting the solidity of foundations ... Transgression contains nothing negative, but affirms the limitlessness into which it leaps as it opens this zone to existence for the first time."

"To transgress is to cross boundaries, but it is boundaries, after all, that mark places" (MacKendrick 1999:3). This place of struggle between establishing a boundary and crossing it, this place of tension, is difficult to find. The place these transgressive pleasures have in tradition is a place of disruption, overriding our understanding of the tradition. As MacKendrick (1999:4) remarks, it is absurd to try to pin-point the place of transgression and set its boundaries. Transgression is perplexing and impassable; its spirit is found in places of rupture and in the work of the philosophers of power, pleasure, and disruption. Bataille understood both the craving for systematic order and the drive to disrupt that order. This is where Dionysius meets Apollo, where spirit lies (MacKendrick 1999:4). The space can be described as edgy at the cut, at the space opened across boundaries where anything may happen. In more than just a physical sense, they can be described as edge-play or limit-pleasures (MacKendrick 1999:18).

The transgression this essay wants to propose as a way of rehabilitating sexual Spirit is not one that wants to break down or negate boundaries. It is one that wants to confirm boundaries. Crossing a boundary does not necessarily negate it if the crossing is not "permanent." For something to be an act of transgression, boundaries against which the act is "perpetrated" are needed. For a boundary to have any meaning, acts of transgression against it are needed. This confirms the boundary. If the modern state pursues its liberal mandate by breaking down boundaries between private and public and between differences and oppositions by striving towards sameness, then it may be a transgressive act to re-establish boundaries. A liberal act (transgression) will be employed to counter the (unintended) harmful effect that the modern liberal state has on Spirit. 
Tension found in transgressing boundaries may, in the end, be how Spirit will be rehabilitated. An important distinction is that the breaking down of boundaries is not purposed, but rather a transgression where boundaries are strengthened. A perpetual positive tension is the aim - a place where Spirit may flourish.

\section{Conclusion}

In building the argument above, I followed the following reasoning: first, Spirit was defined as a synthesis of the concepts of spirituality, the erotic, Rausch and Will to Power as discussed in the first part of this work. The optimum conditions for Spirit to thrive were discussed before the inherent danger the human rights culture hold for Spirit was explored. Before concluding, transgression as a means for liberating Spirit was suggested.

\section{BIBLIOGRAPHY}

Arendt, H. 1958. The human condition. Chicago: University of Chicago Press. Ariès. 1989. A History of Private Life: Passions.

Baudrillard, J. 1993. The transparency of evil. (Verso, Ed.). London.

Borody, W. 2003. Nietzsche on the cross: The defence of personal freedom in The Birth of Tragedy. Humanitas, XVI(2), 76-93.

Burrus, V. and, \& Moore, S. D. 2003. Unsafe sex: Feminism, pornography, and the Song of Songs. Biblical Interpretation, 11, 24-52. Retrieved from http://static1.1.sqspcdn.com/static/f/692273/9425524/1289845338413/Unsafe+Se $\mathrm{x}+$ Song+of+Songs+Pornography+and+Feminism.pdf?token=vV5JDXf243SiF3fe dFkGIVb7n\%2Fw\%3D

Edmunds, A. D. 2013. BDSM: What is that? Seeking a definition to the mis/undefined., (Mais 700), 1-22.

Erasmus, A. 2017. Masters, slaves and spiritual sexuality. University of Pretoria.

Erasmus, A., \& Lombaard, C. J. S. 2017. When equal becomes the same. The spirituality of sex: Have we lost it? Verbum et Ecclesia, 38(2), 1-7. https://doi.org/10.4102/ve.v38i2.1613

Foucault, M. 1977. Language, counter-memory, practice: Selected essays and interviews. New York: Cornell University Press.

Fukuyama, F. (1992). The End of History and the Last Man (1st ed.). London: Penguin Books.

Habermas, J. 1974. The public sphere: An encyclopaedia article. In New German Critique (Autumn, pp. 49-55). New German Critique. Retrieved from http://www.jstor.org/stable/487737?origin=JSTOR-pdf

Houlgate, S. 1986. Hegel, Nietzsche and the criticism of metaphysics. Cambridge: Cambridge University Press.

Irigary, L. 1993. An ethics of sexual difference. New York: Cornell University Press.

Kellner, D. 2000. Modernity and its discontents: Nietzsche's critique.

Lombaard, C. J. S. 2009. Orgasms and hallelujahs, or, Christian spirituality and sexuality: a missionary position. Missionalia, 37(1), 103-123. Retrieved from http://search.ebscohost.com/login.aspx .direct=true\&db=reh\&AN=ATLA000178 
0960\&site=ehost-live

Mabille, M. 2016. Arendt, the body and the loss of the political. Retrieved January 1, 2017, from https://www.linkedin.com/pulse/arendt-body-loss-political-louisemabille

MacKendrick, K. 1999. counterpleasures. Albany: State University of New York Press.

Nietzsche, F. 1996. Human, all too human. (R. Translated Hollingdale, Ed.).

Cambridge: Cambridge University Press.

Paglia, C. 1991. Sexual personae. New Haven: Yale University Press.

Paglia, C. 2017. Free women, free men. New York: Pantheon Books.

Reynolds, J. 2009. The master-slave dialectic and the "sado-masochistic entity" Some deleuzian objections. Angelaki, 14(3), 11-26.

https://doi.org/10.1080/09697250903407492

Sinnerbrink, R. 2007. Understanding Hegelianism. Stocksfield: Acumen Publishing. Tuttle, L. 1986. Encyclopaedia of feminism. London: Arrow Books.

Zukauskaite, A. 2003. Transgression in a sentimental style. Eurozine, (May), 1-10. 